УДК 94(100)“1914/19” + 355.415.8 + 94(470.5) Vladimir Motrevich, Alexandr Smykalin

\title{
WORLD WAR I PRISONERS OF WAR GRAVES IN THE URALS: MODERN STATE
}

This article examines the death rate among foreign POWs held captive in the Urals during World War I and the contemporary state of their burial sites. The author studies the conditions in which POWs were kept in the Urals during World War I, reveals the causes and rate of deaths among the POWs, and characterizes the condition of military cemeteries surviving to the present day. The analysis is based upon documents in regional archives, data from parish registers and field expeditions. The article also describes the memorials for POWs remaining in various parts of the region, such as in Kirov, Orenburg, Sverdlovsk, and Kurgan regions. The high death rate was primarily caused by the region's severe climate and hardships of adaptation. Additionally, many deaths were caused by exogenous factors (typhoid, pneumonia and scurvy). The authores conclude that intensive work needs to be carried out to reveal, maintain and refurbish the burial sites of the POWs of World War I.

Ke yw ord s: World War I; foreign POWs; Urals; camps; parish registers; death toll; epidemics; burial sites.

Работа посвящена смертности размещенных на Урале иностранных военнопленных Первой мировой войны и современному состоянию захоронений в регионе. Исследованы условия размещения военнопленных, выявлены причины и масштабы их смертности в различных районах края. Высокая смертность военнопленных объяснялась, в первую очередь, суровыми климатическими условиями и сложностями адаптации. Причинами смертности являлись экзогенные факторы (тиф, воспаление легких и цинга). В основе исследования материалы региональных архивов, данные церковных метрических книг, а также результаты полевых экспедиций. Описываются сохранившиеся памятники военнопленным Первой мировой войны в Кировской, Оренбургской, Свердловской и Курганской областях. Делается вывод, что предстоит большая работа по дальнейшему выявлению, сохранению и обустройству кладбищ военнопленных Первой мировой войны в Уральском регионе.

Ключевы е слова: Первая мировая война; иностранные военнопленные; Урал; лагеря военнопленных; метрические книги; смертность военнопленных; эпидемии; захоронения военнопленных.

(c) Motrevich V., Smykalin A., 2014

Quaestio Rossica • 2014 • №1 
With the $100^{\text {th }}$ anniversary of the beginning of World War I approaching, the authors have focused on the presence of prisoners of war (POWs) in Russia during the period. According to a broadly accepted view, approximately 2.0-2.5 million soldiers and officers of the Central Powers were held captive in Russia. During the post-Soviet period, a number of works on foreign POWs in Russia were published and devoted to the prisoners of war in the Urals and Western Siberia during World War I and after [Ломцов; Матущак; Сафронов; Суржикова, 2012]. It is estimated that there were approximately 300,000 POWs from the Austrian-Hungarian, German and Turkish military personnel in the Ural region [Уральская историческая энциклопедия, с. 120]. However, the issue of the death rate, the number of war graves, the work that went into the establishment of cemeteries, their distribution as well as their modern conditions have so far remained unstudied. The same holds true for the Urals and Trans-Urals.

Foreign POWs started arriving in the Urals and Trans-Urals during the first months of the war. At the beginning of September, 1914, the first prisoners arrived in Kurgan and later in Tobolsk and Tyumen. As of July 11, 1915, 3,978 POWs were held in Tobolsk, 7,298 in Tyumen Uyezd, and 5,831 POWs in Kurgan Uyezd [ГАТ, ф. 152, л. 2] ${ }^{1}$. To house the newly arrived POWs, the local authorities rented houses from private owners or settled them in public buildings. Later, the authorities constructed barracks and special camps.

By 1917, there were a total of 400 POW camps in Russia. Some of the POW s lived among the locals. In the authors' archive there are over 15,000 place names in the Russian Empire that held military personnel captive during the war. One of the largest POW camps was located in Tobolsk, and in 1916 it was visited by a Danish delegation, which included representatives of the International Red Cross organization.

A surviving Danish report of an inspection of the camp was sent to the governor of Tobolsk by the Tobolsk military censor, A. S. Tyulpanov. In his report, A. S. Tylpanov mentions that the delegation had visited and inspected the Tobolsk labour camp and talked to the POW junior military personnel. The representatives of the delegation examined the utility buildings and the barracks, which were meant to house 500 people each, and noted their cleanliness and satisfactory amenities. The POWs were unanimous in their opinions of the effectiveness of postal delivery, pointing out that on a number of occasions their mail reached home within 21 days after having been posted in Tobolsk. The next day the delegation visited a settlement $12 \mathrm{~km}$ away from the city where there were 165 Austrian-Hungarian officers and 55 junior military personnel. The delegation noted that two officers apiece shared detached houses in a pine forest. The POWs equipped the territory with all the necessary facilities, built a stadium, planted a garden and fir-trees as well as grass in front of their houses; they also engaged in pig farming.

However, this idyllic picture was not to seen everywhere. According to B. I. Nikmanov, medical care generally was not provided in the labour

${ }^{1}$ It is important to note that the numbers of POWs can be determined only approximately, as POWs were often transported from one place to another. 
camps. Doctors were chosen from among the POWs, but they did not receive any support from the camp authorities. Nor do the aforementioned sources contain any information about the supply of camps with medicines. Due to very harsh conditions of detention, the death rate in the camps was very high. Additionally, due to the fact that the camps were overcrowded, it was impossible to provide separate lodgings for the diseased, who frequently ate and lived together with the healthy POWs. All these combined with a very basic food supply caused an adverse epidemiological situation in the camps. For instance, in the Totsk camp (Orenburg region) an average of 80 persons died from typhus daily. And between November 1915 and January 1916, an estimated 11,000 POWs died in the camps [Ниманов, с. 15].

In case of illness, POWs were transferred to town hospitals and sick quarters. The deceased were interred in military and town cemeteries. The parish register of the Tobolsk Roman-Catholic Church recorded the causes of death for the POWs. Overall, between 1914 and 1915, 102 POWs died and were buried in the Zavalnoye Cemetery. The most frequent causes of death were tuberculosis, dysentery, typhoid (44 POWs died of typhoid, 32 of tuberculosis and 9 of dysentery). In 1916, 118 POWs died in Tobolsk, 82 of whom died of tuberculosis [GAT, f.156, 1.134 - 170]. A similar range of causes of death can be found in other parish registers. The parish register of the Revdinskiy Plant of the Perm region contains data about 43 deceased POWs, listing similar causes of death: typhoid, tuberculosis, and pneumonia. According to the parish register of Transfiguration Cathedral, 304 POWs among the Austrian-Hungarian, German and Turkish military personnel died between 1915-1919 in Nadezhdinsk (Serov). Another notable cause of POWs' death was scurvy, which may be ascribed to the severe climate of the region and inadequate nutrition. Thus, in a majority of cases, POWs' deaths were caused by exogenous factors with typhoid, pneumonia and scurvy prevailing. N. V. Surzhikova comes to a similar conclusion, stating that 77 out of every 100 POWs in the Perm region did not live longer than 40 years [Суржикова, 2014, с. 322].

How were the personal belongings of the deceased POWs disposed of? In Russia, there existed the so-called Rules of sending home the belongings of the deceased, fugitives and other POWs of enemy armies. In compliance with this document, all the items of POWs' uniforms of the junior military personnel were to be handed over to the local commissary. All the remaining items (plain clothes, underwear, footwear, etc.), providing their condition was satisfactory, were to be disinfected and given to other POWs; all the rest was to be disposed of. Documents, letters, decorations, medals and notebooks were to be sent to the Central Inquiry Office in Petrograd and accompanied by a document indicating the details of the deceased: their name, age, religion, place of birth, and army in which they had served (German, Austrian-Hungarian or Turkish) [Жарова].

In Tobolsk, the military censor's, A. S. Tyulpanov, report to the governor of Tobolsk contains exclusive data on the condition of the POW cemetery during the visit of the Red Cross representatives. According to them, the POW 
cemetery was a plot of land in the forest adjoining the edge of the Zavalnoye Cemetery of Tobolsk. The cemetery was divided into sections. Flowers were planted around gravesites; the fence and gate were made of birch, and the gate had an inscription: "Here lie prisoners of war". There was a path in the centre of the site with ditches for water drainage on its sides. The deceased POWs were buried in wooden coffins. As an exception, a Hungarian officer, Nagy, was buried in a metal coffin due to the fact that there was a request to repatriate his body. Every grave had a birch cross over it with the name of the deceased POW and the date of death; in the middle of the cemetery stood a black, Catholic cross. The same document demonstrates that POW cemeteries around Saint Petersburg were in a much poorer state.

During World War I, tens of thousands of POWs died in Russia. They were buried in cemeteries scattered all over the country and in specially created burial sites. Memorials to World War I, foreign POWs built in 1918 have survived until the present day in Kirov, Orenburg, and Sverdlovsk regions. For a temporary period, Austrian-Hungarian POWs were transferred to the town of Slobodskoy, the present Kirov region, and to other towns of the Russian Empire. Initially, the POWs were subject to the military authorities' control, but in mid-1916, the majority was released from custody. Between 1915 and the beginning of 1916, the town faced an epidemic of typhoid, which caused a great number of deaths among POWs. To care for the diseased, authorities built typhoid barracks. The dead were buried in the south-eastern part of the town cemetery, which was located on the picturesque bank of the Vyatka River. In 1918, a monument was erected in the place of POWs burial. The obelisk in Slobodskoy was a tall, four-sided column standing on a stepped base adorned with garlands and finished with a stylized eternal flame. On top of it, the monument had a flying eagle, which is now missing. The monument was made of brick and white stone - the latter was used to make the flame - garlands, wreath, and columns. All four sides of the column have niches in them with metal plates bearing inscriptions in Russian and German.

During World War I, over 5,000 POWs were held captive in the north of present-day Sverdlovsk region in the city of Serov (known as Nadezhdinsk at the time). Part of the POWs worked at the Nadezhdinsk Metallurgical Plant, while others built a railway. The POWs' working conditions were monitored by representatives of the Swedish Red Cross; however, they did not comply with the requirements. The POWs working at the plant were provided with more or less satisfactory working conditions, while the rest of the POWs had to suffer from much harsher conditions. Thus, POWs building a railway were forced to manually dig frozen ground using pick hammers and spades in the winter, and had to live in dugouts, which were characterized by their darkness and excessive humidity. According to the parish registers of Transgression Cathedral, approximately 304 POWs died in Nadezhdinsk (32 in 1915; 112 in 1916; 102 in 1917; and 57 in 1918, respectfully). The low death rate among POWs in 1915 can be ascribed to the fact that at that time POWs had just started arriving in Nadezhdinsk, and 
in 1918 the repatriation process began. Like the majority of POW camps, in Nadezhdinsk they died from diseases (tuberculosis and scurvy). However many were victims of accidents (e. g., a POW died in an open-hearth shop as a result of carbon monoxide poisoning; another was hit by a train; yet another drowned in the river). Additionally, there were cases of suicide. The deceased POWs were buried in the town cemetery, and in 1918 the construction of a commemorative monument was funded by the Bogoslovsky mining district. The monument was $2.5 \mathrm{~m}$ tall and was made of concrete, imitating natural rock. In the 1950s the cemetery was destroyed. The locals tried to demolish or topple the monument, but their attempts to do so were ineffective. This is how the monument found its place on the property of a privately owned house built there. The plate on the monument is missing as well as the iron chain, which at one time circled the monument.

In the Perm region, POWs working at the Revdinsky Hardware Plant were involved in lumbering and in the building of a railway. During the 1920s, workers from Revda collected money and erected a 2-metre stone pyramid at the POW burial site. The plate on it read: "To our brothers in class. To victims of the world capital. From the workers of Revda."

Monuments over 3 metres in height still survive in the town of Nizhnyaya Salda (Sverdlovsk Region) and in the town of Totsk (Orenburg Region). However, it was not a tradition to erect monuments in honour of POWs everywhere, and much work is yet to be done to find, preserve and refurbish the POW cemeteries of World War I. The goal is attainable, nonetheless, since the Ural region is characterized by low population density and land development. Due to these factors, many of the POW burial sites survive, although often there may be no visible indication. This situation applies, for example, to the POW burial site, destroyed during the 1970s, on $9^{\text {th }}$ January Street in Kurgan [ГАКО, ф. 465, л. 75, 76]. At present the Victory Park is located there; however, if necessary, the POW site could be uncovered.

Recently work has begun to re-discover and maintain POW burial sites of World War I, both abroad and in Russia, particularly thanks to the intensive efforts of the Österreichische Schwarze Kreuz (The Austrian Black Cross). Because of their work, a memorial was built in the burial site of World War I POWs in the destroyed Ryazanovskoye Cemetery in Yekaterinburg.

ГАКО. Ф. 465. [GAKO. F. 465.]

ГAT. Ф. 152; Ф. 156. [GAT. F. 152; F. 156.]

Жарова А. С. Положение военнопленных Первой мировой войны в Тобольской губернии. [Электронный ресурс] // Зауральская генеалогия. URL: http://kurgangen. org)local-finding/Pervaya Mirovaya/Plen/ (дата обращения: 30.12.2013). [Zharova A. S. Polozhenie voennoplennykh Pervoi mirovoi voiny v Tobol'skoi gubernii [Elektronnyi resurs] // Zaural'skaya genealogiya. URL: http://kurgangen.org`local-finding/Pervaya Mirovaya/Plen/ (data obrashcheniya: 30.12.2013).]

Ломиов А. А. Военнопленные в Южном Зауралье в годы Первой мировой войны // Социально-экономические отношения в Сибири и на Урале во второй половине XIX-XX вв. : материалы регион. науч. конф. (г. Курган, 21 дек. 2000 г.) / [отв. ред. 
П. А. Свищев, В. Г. Савельев]. Курган : Изд-во Курган. гос. ун-та, 2002. С. 78-87. [Lomtsov A. A. Voennoplennye v Yuzhnom Zaural'e v gody Pervoi mirovoi voiny // Sotsial'no-ekonomicheskie otnosheniya v Sibiri i na Urale vo vtoroi polovine XIX-XX vv. : materialy region. nauch. konf. (g. Kurgan, 21 dek. 2000 g.) / [otv. red. P. A. Svishchev, V. G. Savel'ev]. Kurgan : Izd-vo Kurgan. gos. un-ta, 2002. S. 78-87.]

Матущак Л. В. Военнопленные Первой мировой войны на Урале // Проблемы военного плена: История и современность : материалы междунар. науч-практ. конф., 23-25 окт., г. Вологда : в 2 ч. / редкол.: Е. А. Поромонов (предисл.) и др. Ч. І. Вологда, 1997. C. 173-174. [Matushchak L. V. Voennoplennye Pervoi mirovoi voiny na Urale // Problemy voennogo plena: Istoriya i sovremennost' : materialy mezhdunar. nauch-prakt. konf., 23-25 okt., g. Vologda : v 2 ch. / redkol.: E. A. Poromonov (predisl.) i dr. Ch. I. Vologda, 1997. S. 173-174.]

Ниманов Б. И. Особенности и основные факторы содержания и хозяйственной деятельности военнопленных в 1914-1917 годах : автореф. дис. ... канд. ист. наук. М., 2009. 24 c [Nimanov B. I. Osobennosti i osnovnye faktory soderzhaniya i khozyaistvennoi deyatel'nosti voennoplennykh v 1914-1917 godakh : avtoref. dis. ... kand. ist. nauk. M., 2009. 24 s.]

Сафронов Д. А. Немецкие военнопленные в Оренбургском крае в годы Первой мировой войны // Немцы и Оренбургский край : сб. ст. и тез. / под общ. ред. A. В. Федоровой. Оренбург : Димур, 1994. С. 24-26. [Safronov D. A. Nemetskie voennoplennye v Orenburgskom krae v gody Pervoi mirovoi voiny // Nemtsy i Orenburgskii krai : sb. st. i tez. / pod obshch. red. A. V. Fedorovoi. Orenburg : Dimur, 1994. S. 24-26.]

Суржикова Н. В. Военнопленные в Богословском горном округе: контакты, конфликты, конвенции // Изв. Урал. федер. ун-та. Сер. 2. Гуманитар. науки. 2012. № 1 (99). C. 123-125. [Surzhikova N. V. Voennoplennye v Bogoslovskom gornom okruge: kontakty, konflikty, konventsii // Izv. Ural. feder. un-ta. Ser. 2. Gumanitar. nauki. 2012. № 1 (99). S. 123-125.

Суржикова Н. В. Военный плен в российской провинции (1914-1922 гг.). М. : Росспэн, 2014. 424 с. [Surzhikova N. V. Voennyi plen v rossiiskoi provintsii (1914-1922 gg.). M. : Rosspen, 2014. 424 s.]

Уральская историческая энциклопедия / гл. ред. В. В. Алексеев. Екатеринбург : Екатеринбург, 1998. 624 с. [Ural'skaya istoricheskaya entsiklopediya / gl. red. V. V. Alekseev. Ekaterinburg : Ekaterinburg, 1998. 624 s.]

Translated by Tatiana Kouznetsova The article was submitted on 17.12.2013

Мотревич В. П., проф. Россия, Екатеринбург Уральская государственная юридическая академия vladimir.motrevich@mail.ru

Смыкалин А. С., д. ю. н. Россия, Екатеринбург Уральская государственная юридическая академия smykalin@mail.ru
Vladimir Motrevich, prof.

Russia, Yekaterinburg Ural State Law Academy vladimir.motrevich@mail.ru 